DOI: 10.2478/rae-2020-0013 Review of Artistic Education no. 192020 100-109

\title{
13.THE SYSTEMATIC OF THE CHARACTERS FROM THE OPERA A STORMY NIGHT BY PAUL CONSTANTINESCU
}

\author{
Consuela Radu-T,aga ${ }^{137}$
}

\begin{abstract}
In the history of the Romanian musical theatre the comic opera A Stormy Night written by Paul Constantinescu set up the buffa style. All along the two acts carried out in approximately 50 minutes you can hear Romanian folklore resonances, with Anton Pann echoes, as the 7 characters from the opera live in the Bucharest of the 19th century. The leitmotif technique is at the basis of the musical story, 9 melodious-rhythmic configurations getting detached. The musical discourse of the singers is entirely subordinated to the text, and the ample breath appeals to the recitative singing, which evolves towards arioso. The categorical overlapping of the musical declamation with the spoken language initiates a route in which we encounter phenomena such as sprechgesang, parlato, yelling, buffa slipping of the voice. The characters are $X$-rayed with a deep critical spirit and the capacity to illustrate funny situations gains a lot from Constantinescu's experience.
\end{abstract}

Key words: comic opera, leitmotif, character, urban folklore, musical declamation

\section{Introduction}

In the years of the birth of Oedip tragedy, the Romanian musical theatre launches its first lyrical original comedy, setting up the buffa genre through the Opera A Stormy Night. The distinct notes of the two creators are related to the irrefutable deconventialising of the musical discourse, through the means taken out of "the same modern phenomenality of transforming the human voice into music" [2, p. 20]. Through the intensely theatrical uttering, the feelings are transcribed directly, into a language situated as intonation between speaking and singing, either far from both of them or closer to one or the other. The categorical overlapping of the musical declamation with the spoken language evolves on a route on which we encounter phenomena as sprechgesang, parlato, yelling, buffa slippings of the voice ${ }^{138}$.

The temptation towards the comic opera registers Paul Constantinescu on a route which has its origin in the vaudevills of the 19th century, route continued by the operetta genre. For the structure of the musical basis, Paul Constantinescu draws on Anton Pann's ${ }^{139}$ collection of songs: Spitalul Amorului [The Hospital of Love] or Cântătorul dorului [The Singer of Longing]. Thus, the urban folklore with heterogenous character is valued (with oriental and western influences) and the musical treatment uses modern composing methods, reminding us of the

\footnotetext{
${ }^{137}$ Lecturer PhD., "George Enescu” National University of Arts from Iaşi, Romania, email: taga_consuela@yahoo.com

${ }^{138}$ In the initial version of the opera A Stormy Night, Spiridon's score was completely recited.

139 Belonging to the Roma population, Anton Pann (1794-1854) carried out an intense musical activity, being considered the first literary and musical folklorist in Romania.
} 
rythmic contexture of Stravinski's opuses.

The action of his first opera, composed at the age of 25, is set in Bucharest, at the end of 19th century, in Master Dumitrache's house. The Caragiale characters are distributed on categories of voices as it follows:

- Master Dumitrache (called Titircă bad-heart)

- Nae Ipingescu, sergeant political friend of the captain

- Chiriac, shop assistant, guard sergeant Dumitrache's reliable person

- Spiridon, servant in Titircă's house helper boy

- Rică Venturiano, law student judge archivist, editor

- Veta, Dumitrache's wife

- Zița, Veta's sister

\author{
bass \\ baritone \\ tenor \\ mezzosoprano \\ mezzosoprano \\ (alto) \\ tenor \\ soprano
}

\section{Master Dumitrache}

Following the pattern of the mask characters taken from commedia dell'arte, Master Dumitrache, the main character in the comedy A Stormy Night represents the embodiment of the naive husband. In the leitmotif of Master Dumitrache you can feel an oriental flavour, being a sound representation that has the sign of durability of certain visions from the Fanar period. The bass role of Master Dumitrache reminds us of the character Don Bartolo from the buffa Opera The Barber of Seville by Gioacchino Rossini, but he is a Don Bartolo from the banks of Dâmboviţa.

His self image is equivalent to one of an honourable citizen, the respect of the people around him being imposed through the good reputation of a family man. His activity as a merchant, doubled by that of captain in the civic guard, raises him in the social hierarchy, giving him the right to present himself as an imposing person, endowed with real and multiple qualities. His gesture of caressing his whiskers, mentioned by the playwright, is the expression of stupid vanity, the stress being focussed on the very good opinion that he has about himself.

The dialogue Dumitrache-Ipingescu stands out as a soliloqui of the merchant, Nae's replies being just a few and short. Ipingescu is dominated by Dumitrache through intensity, ambitus, complexity of writing, of vocality, the sergeant adopting subserviently the merchant's opinions, completing or murmuring a simple rezon. This monologue literarily dynamized is carried out in one breath by repeating the conjunction iar $^{140}$, the precipitation of the exposition asking for the musicality of the action. The increase of intensity is done gradually, both vocally, and with the orchestra, this one constituting a support for the vocal

${ }^{140}$ but 
expressions that occur in the musical discourse.

The convincing discourse of the master, carried out in quite a limited ambitus, as well as the vocal bravery, full of decorative effects, do not represent marks of subtlety or of behavioural elegance, but present an uneducated character, an exponent of stupidity, of naivity and of barren feelings. When the pattern of the chatter is not straight, his vocal line presents jerky sounds.

The sketching of Master Dumitrache's personality is done also through the character Nae Ipingescu. The collocation $d$-ai noștri ${ }^{141}$, with the help of which Nae Ipingescu recommends Master Dumitrache to the journalist Rică Venturiano, imposes the attachment to the political party represented by the liberals, highlighting the democratic atttitude of the character with a wide perspective. Dumitrache's stupid fixation on his onoare de $\operatorname{sot}^{142}$ obturates his perception on the reality, the immense credit that he grants Chiriac, changing him into a ridiculous character. As a family man, he takes the following rights: of not having his honour of a family man being betrayed and the ambition of not making a fool of himself in front of the world. The Caragiale spirit touches the peak of irony, as Master Dumitrache embodies the type of the cheated husband.

\section{Nae Ipingescu}

The character Nae Ipingescu is the least described in the context of the action and this is not because of an omission or a lack of imagination of the creator, but because he is a dull person, who does not have special qualities. In his friendship with Dumitrache, Master Nae is dominated by the authoritative temperament of the Master, unanimously accepting all his opinions. In the discussions of the two men, Nae Ipingescu's replies are short and few, highlighting thus the submissive attitude. The sergeant does not only agree with the Master's statements, but follows him in all the actions: saving Ziţa from Țîrcădău's hands or the catching of the nocturnal impostor. His important mission is that of recognising in the pursued person the author of the article that they had read in the evening.

\section{Veta}

Master Dumitrache's wife is a mature woman, who wants to seem, next to her husband, worthy of respect in the Bucharest suburbs. She easily assumes the posture of a faithful wife, in fact choosing menaj à trois. Binding her husband's eyes, Veta offers herself to Chiriac that she scolds for believing the jealous husband's suspicions. When the relationship with her lover seems to be over, Veta is heart broken, sad and absent, the unhappiness giving her a mood of morbidity. In her case, the comic of the situation is the one underlining the imoral profile. The fake suicide from the reconciliation scene wakes up in Veta unknown energies. The obstacle in committing the terrible thing constitues the vows of

\footnotetext{
141 our people

142 honour as a husband
} 
innocence expressed in a typical suburban language: să n-am parte de viața mea, de ochii mei, na, ce mai vrei? De-s vinovată cu ceva! $!^{143}$ In a sentimental soliloqui carried out on an beginning of romance, Veta, uncomforted and disappointed, sighs deeply. "The sonority of this romance is a little similar with the Russian romance, even with Lenski's romance from the Opera Evgheni Oneghin by Ceaikovski" [6, p. 50]. Just like an uncaressed sigh, the ascending leap of a perfect fourth determines the genealogy of the whole musical evolution (scene VIII).

The meeting of the two lovers leads gradually towards conciliation. From the passionate statements to the threat with the suicide, the happy solving of the conflict generates a hot love scene. From the musical point of view, the particularity of the pair of lovers is portrayed in a very subtle way. Veta, a merchant's wife, a woman without too much personality in front of an indifferent husband, who is a tyrant, as well, that she cheats without any scruples, uses the whole sentimental arsenal offered by the expressive valences of the romance genre. On the other hand, there is the folk song which is part of Chiriac's sphere. It results an overlapping between romance and folk song, this fusion being the osmosis between the tonal system and the modal one. "Chiriac is a cardboard Canio, with a Dâmbovițean specific, who attacks, blinded by jealousy, the woman he loves. The difference is that Nedda from the Opera Pagliacci by Leoncavallo was the adulterous wife, whereas Veta is the innocent ... mistress. Canio kills his unfaithful wife, while Chiriac simulates ... the suicide" [6, p. 5152].

Veta sings the fulfilling of her dream singing a languorous tune, harmonically stylized, the chromatic comprising everything in a pleasant drowsiness. The romance Într-un moment de fericire ${ }^{144}$ brings again in the first plan the singing accompanied by the piano. The beginning of romance is continued with a fragment in which the string orchestra is essential, the female character uttering a few spoken lines. Veta's falling asleep is musically expressed by decreasing and thinning the tune; she sighs with happiness, the portrait of her lover slipping into her soul.

\section{Chiriac}

Through a sort of arioso with a less obvious tune, Chiriac is made known to the public in the second scene. His coming is escorted by the trumpets playing a major arpeggio with a major seventh. Confident, as a guard sergeant that he is, Chiriac is musically characterized through a trumpet signal, the first leitmotif of the character transmitting military echoes. The way in which Chiriac behaves with his master is described through the ondulatory, waving line of the second leitmotif of the character. The musical image talks about the temperament of the person, about the sharpness of the mind underlined by the rythmic formula, but also about

\footnotetext{
${ }^{143}$ Not to benefit from my life, my eyes, what else do you want? If I am guilty! (t.a.C.R.T).

${ }^{144}$ In a moment of Happiness.
} 
slyness and hypocrisy, features suggested by the tune. The sinuous leitmotif will evolve together with the character placed in various situations, while the first leitmotif has the simple role of preamble. Only Chiriac has two musical structures, the other characters having only one each.

Chiriac represents the third side of the conjugal triangle. The person to whom Master Dumitrache hands out the care of his whole house, including the high honour of guarding with sanctity his family honour, Chiriac proves to be a quick person, confident, but duplicitous, who desires to ascend socially on a sinuous route. His relationship with Veta is the image of mature love in contrast with the teenage love between Zița and Rică. His hypocrisy is observed in the moment of the suicide miming, but especially after the love scene. The comic of situation resulting from Chiriac's behaviour is obvious. The lover, holding strongly to his chest his beloved, responds, convincingly, to the husband who has doubts about the unknown man from the Iunion: lasă pe mine jupâne, mă știi bine, când promit.. ${ }^{145}$ Jealousy is a strong feeling for him, he feels that somebody threatens his position that he got to with a lot of work. His energy is equivalent to that of Zița, their actions being full of dynamism. To prove this, it is enough to thin about the scene of looking for the vagabond, in which Chiriac is the number one pawn. The end of the play puts him in the ridiculous situation, of admitting with a special ingenuity, that the scarf belongs to him, saving thus the honour of the loved woman and, implicitely, of Master Dumitrache that he serves.

Paul Constantinescu uses a means specific to the comic opera: imitating the characters by making a voice parody of the vocal feature, intending to obtain a funny effect (Chiriac in the IInd scene, Spiridon in the Vth scene, Ziţa in the VIIth scene). Two essential parameters compete to the illustrating of this meaning: on one hand, the agogics imposed by the composer and conducted by the conductor and on the other hand the vocal colour of the singer. The vocal emission totally different, the face mimic, the gestures and body language are especially important aspects. When the servant of Master Dumitrache speaks about his own facts, the tempo is alert and when he imitates the beggar voice of the pretended sick person, the tempo is more gentle. Any time this agogic succession intervenes, the alert sections being predicted by the first leitmotif of Chiriac, while the second leitmotif is distributed to the slow sections, submitted to sequencing and chromatizing. The sounds emitted by Chiriac when he imitates Tache The Shoemaker have to be spread, contouring an open, a little nasal sonority.

\section{Zița}

Embodying the type of the coquette suburban woman, Ziţa evolves on the line of the female characters from the comedy D'ale carnavalului, fitting in Didina Mazu and Mița Baston's world. The impression of an educated, mannered and obedient woman is annulled by the rough way of expressing herself, her trivial habits and her sly behaviour. Secretely exchanging notes with Venturiano,

\footnotetext{
${ }^{145}$ leave on me, master, you know me, when I promise...
} 
through Spiridon, a nocturnal invitation, at her place, and, in the end, putting her eyes in the ground, accepts to sympathise together with the young journalist, only with the blessing of the Master. This one, appreciating his sister-in-law as being $a$ beautiful girl, fashion girl and educated for three years in a boarding school, has paternal feelings for her. Sharp-minded, Zița wants to live a fashionable life. The marriage with Ghiță Țîrcădău was a failure, as this one was treating her with slapping and insults. This is why the brother-in-law intervened, accompanied by Ipingescu, helping her to get divorced.

All the noise and the chaos are created by Zița, this triggering the hilarious situation that constitues the subject of the comedy. Ziţa's ignorance is distinguished in the funny language in which the suburban words and phrases combine ridiculously with neologisms, most of them altered. The scene in which Zița tells us about the meeting with her former husband, the latter one insulting her in the street, is remarkable. The insults jerk, bastard, enriched, pastrami boy that she uses on Țîrcădău are mixed with French origin words and phrases, adapted to her vocabulary: bonsoar, sans fason. Finally, Ziţa is meant to have a happy fate, her love hopes getting fulfilled by marrying the young Rică Venturiano.

The note brought by Spiridon transforms Rică Venturiano's song in a an emanation of exaggerated sensitivity - specific to the suburbs - meant to portray the urban framework of the end of the 19th century. By choosing the waltz pulsation the city spirit is described, the waltz being here the expression of the love between Rică and Zița. The latter one gives herself away lyrically singing Inger radios ${ }^{146}$ on the motif of Romanian vintage romance Mai am un singur dor ${ }^{147}$. The combination of these two musical types, on one hand the Romanian romance, on the other hand the slow Wien waltz, results in an immersion that represents the musical home of the characters who have aspiratios to rise in the social hierarchy. The end of the excitement is illustrated through a Paris atmosphere, the female character abandoning herself to the waltz. The new sonority of the accordion, a popular instrument, used both on the banks of the Seine and also by the people in Bucharest ${ }^{148}$ is to be noticed. The approach of the Wien waltz requires the clear stating of the tonal system. Zița's tune (musically characterised in scenes VI and VII) asks for an elastic, graceful execution, in legato manner, both in the department of the wind instruments and of the lead singer.

The dialogue between the talkative Zița and the enigmatic Veta conveys the mood of each of them. The dynamic metamorphosis contain the carrying out of the dialogue, asking from the singers a high degree of virtuousness. By extrapolating, the toccata term can be attributed to this spark. In the coda section Zița leaves yelling and thus there is a fragment of sprechgesang, above an

\footnotetext{
${ }^{146}$ Radiant Angel

${ }^{147}$ I have only one longing

${ }^{148}$ Between the two world wars Bucharest was called the little Paris.
} 
ochestral fugato.

\section{Rică Venturiano}

From the diversified expression of the comic defining the contradiction between the essence and the apparence, the main features of the character Rică Venturiano come out. Posing in an intelligent character and a quick-eyed journalist, an incontestable value of the society he lives in, Rică's substance is that of a barren-elbows, having an artificial education and proving to have a pathetic cowardness. His intellectual imposture attracts the philistine image of the character. This, from the physical point of view, reunites the particularities typical to the profession of the clerk, reduced to a few representative elements: glasses, topper and walking stick.

Illustrating the guild of the rich merchants, Master Dumitrache disregards the guild of the clerks, of which Rică Venturiano is a member, as well, calling these some charlatans, some scribs. The suburban phrases help characterise directly the character, the young man being labelled as an employee. The expression of the song of French trubadours seems to be parodically reflected, in time, in the exalted love statement of the journalist, famous through the funny language: Radiant Angel. When he realizes the chaos of the situation created by his confusion, Rică proves to be weak, the fear of not being surprised in an infamous context overwhelming his whole being. The incoherence of his language is funnily surprised by means of the anacoluthon: Mă duc, scuzați, pardon, madam $^{149}$.

The clock strikes 11, announcing the moment of the love meeting between Zița and Rică Venturiano. Being in the dim light of the room, Rică throws himself at Veta's feet, posing pathetically and uttering his lyrical effusions with his hand on his heart. His passionate lyrics dedicated to Zița, on the tune of the leitmotif Radiant Angel, sung already by the person it is dedicated to with ingenuity, in the scene with the reading of the note, fail the right address. The thematic significations are combined with the leitmotif of the Iunion, and the arioso of the young man is sung in a viennese waltz tempo. The impetuous attitude of Rică is diminshed by the dissonant reaction of Veta. As she is surprised in her decency, she considers herself attacked. The moment is of a ridiculous drama. Veta'does not present the slightest interest for her.

Surprised by Veta's screaming, Rică moderates the tempo of the sound introducing a romance in tempo of slow waltz. The double apoggiatura that gives beauty to the lead singer is an exhibits of the well known abbelimenti characteristic to the lyrical tenor. Not only the typology of the character indicates this thing, but also the way in which the tune is built, with its high tessitura.

Once the confusion understood, Rică Venturiano starts a tirade of excuses and explanations. Being late in leaving the room, the prolonged explanations put

\footnotetext{
${ }^{149}$ I am leaving, excuse me, pardon, madam.
} 
him into trouble. Rică's departure through the window hurries the music, as the dazzling following of the vagabond is next, Dumitrache and Ipingescu promising revenge. The music is unleashed in an expansive con fuoco manner. A torrent of seconds and thirds in a chromatic walking gradually or abruptly, as well as loud resonances individualised as some swords fighting, corroborated with a fierce anger, are sung in an orchestral tutti extremely nuanced, carried out in fortissimo. The number of the singers in the collective singing is growing, a vocal quartet occurring on the voices sporano, tenor, baritone and bass. It is an ensemble which "exactly as the last act of the Opera Rigoletto by Giuseppe Verdi, conveys the thoughts and feelings of each of the characters, on a personal, individualised line" [5, p. 279]. The two-way correspondence of the musical number with the furious action highights the dissonant liveliness of the orchestral colours, the scales of folkloric origin of the winds mixing with the strongly rythmic interference of the brass and of the string quintet. On a precipitated recitative, the voices are arranged in a disarticulate murmuring.

\section{Spiridon}

Among the seven characters of the distributions we notice the travesti role of Spiridon: poor boy in Titircă's house (the voice of a 14-16 year old boy). This character is interpreted by a mezzosoprano, considering the compatibility of this voice with that of a teenage-boy. The appearance of Spiridon marks the debut of scene III. His whining leitmotif is played by the mixture clarinet-bassoon and viola-cello. Between Master Dumitrache and Spiridon there is a dialogue built on a tempo alternation. Spiridon whines in a rare tempo, the thread of the tune having folkloric resonances (the augmented second), and the anger of the merchant grows involving the acceleration of the tempo. The two meanings are in a report of inverse proportionality, stimulating the whole musical-dramatic route.

Family boy, good at everything, Spiridon is smart enough to understand certain situations which he takes part in without wanting this, that he observes or just feels. His modest origin could not ensure him a lazy life and this is why he had to learn early on in life to get along. Intending a certain gain (money or tobacco) he is always ready to do several tasks. Serving Master Dumitrache, he is harassed by this one day and night, as the Master unburdens all his problems on him. Spiridon tolerates his behaviour, but cannot stop the feelings of revolt that he expresses only in loneliness. By mediating the exchange of notes between Rică and Zița he is a pawn, helping the triggering of the conflict.

Spiridon reappears in scene $\mathrm{V}$, singing a song which was introduced in the repertoire of the mezzosopranos, in spite of its compressed dimension. The song with suburban echoes conveys the social condition of the character, as well as his placing in the area of the city in which he lives. Related to the context of the action, the quick aria expressses the feelings of revolt towards the persecutions that Spiridon stands from the master. The sonority of an authentic Romanian style, as well as the elaboration of a stanza construction are aspects leading to its cutting 
from the context of the opera. On a rhythm of fiddlers' sârba and an orchestra that imitates the sound of the cimbalom, the aria has the structure of a tripentapartit lied. The staccato monorhythm of the vocal part is specific to the rebel teenager, the few sincopas or the longer sounds, as well as the modal intonations with augmented seconds being elements that pigment the musical-dramatic discourse. The spoken intonations, supported on a good diction, are situated in the area of the regular speech, briskly articulated. Together with the dynamics and the stage play, the vocal emission is changed in the sentences attributed to Master Dumitrache. Thus, the singer intends the differentiating between his own voice and imitating the voice of the master. Practically, the musical uttering of this aria is equivalent to the description of Dumitrache through Spiridon's eyes and mind.

The adopting of certain movements contrasting to the elastic ones, in the case of interpreting female roles in travesti, is indispensable for the creation of the body language. In the superior part of the body, the hands do not gesticulate and the embracing of the female-partners is done under the arms (in the armpits area) and not with the hands around the necks. The hip movements have to be avoided, the muscles of the buttocks being tense; in the static moments, the legs will be perfectly stretched and a little more spread. At the same time, the roundness and the protuberances are camouflaged with the help of make-up details and of small tricks that can contribute to the obtaining of an interpretative success by creating a credible male character: "More present than ever, the issues of the travesti cannot be ignored or minimalised... The opera, as the show of the musical shows, is the receptacle of these changes, in the shell of which the past exists as an argument or an excuse, as an obligation to let the fantasy free" [1, p. 150].

In the opera A Stormy Night, Spiridon is a colourful spot. The 400 years of the opera history have registered numerous travesti roles, this procedure of replacing the characters constituting the way to which people have frequently and constantly appealed to. After the period of the Baroque, the specific and unsmistakable sonority of the voices singing the other gender has extended, from the using of castrated men to female voices playing male roles. On the line of the roles children-boys, being situated somewhere at the limit of teenage years, we have tzar Feodor from the Opera Boris Godunov by Musorgski. The innocent witness to all the historical events sings simple, childish songs, impregnated by a strong Russian specific. We notice certain similarities between Spiridon's situation and Cherubino's situation, from the Opera The Marriage of Figaro by Mozart, especially at their entrance on the stage. At the count's castle, Cherubino does not live in Avraam's busom, but is scolded all the time, being saved from the troubles also by a woman (the countess).

\section{Conclusions}

The characters are full of colour, being sympathetically characterised by the attitudes they adopt, as well as by their way of expressing themselves. We can observe Veta's gravity, Zița's lyrical attitude, Master Dumitrache's naivity, 
Rică's intellectual imposture, Nae Ipingescu's protocolar bureaucracy and Chiriac's bad manners.

The musical discourse of the singers is entirely subordinated to the text, fact which offers to the story a quasi-visual plasticity. The sung recitative which evolves towards arioso in Paul Constantinescu characterises the dramatic moments of the opera, giving them eloquence and pathetism through a unitary sequence, of a large breath. A music thus conceived makes us think about a music close to Ravel's music from L'heure spaniole, at the same time, presenting similarities with the Russian recitative realism of Musorgski or Dargomîjski, or can be the reply of the musical intonation that Janáćek deduces expressively and in a programmed way from the inflexions of the speaking.

The Opera A Stormy Night succeeds in projecting through sounds a credible atmosphere due to the agglutination in the tunes taken from city folk music, fiddlers' music as the constituent elements of the salon romance. The rhythmic specific of the folklore is not omitted, but presents less interest for the composer seduced by the melodious dominant, especially by the vocal type. An exceptional caricaturist, Paul Constantinescu has a certain naturalness in his satyrical and humouristics intentions, having the same critical spirit of the man from the same city, Ion Luca Caragiale, that he openly admired.

\section{References}

1. Agache, M. (2007). Personaje lirice în travesti pentru vocea feminină gravă, [Lyrical Characters in Travesti for the Low Female Voice]. Iași: Editura Artes.

2. Ciortea, T. (1967). Universalitate și spirit național în artă, [Universality and National Spirit in Art]. București: Editura Astra.

3. Constantinescu, P. (1962). Cum l-am văzut pe Caragiale în muzică, [How I Saw Caragiale in Music], Muzica magazine no. 6. București: Editura Muzicală.

4. Constantinescu, P. (1958). O Noapte furtunoasă, [A Stormy Night]. București: Editura Muzicală.

5. Cosma, M. (2001). Opera în România privită în context european, [Opera in Romania Seen in an European context]. București: Editura Muzicală.

6. Dumitriu, L. (2008). Caragiale in teatrul liric, [Caragiale in the Lyrical Theatre], vol. I, comic opera. București: Editura Muzicală.

7. Tomescu, V. (1967). Paul Constantinescu. București: Editura Muzicală.

8. Vieru, A. (1956). Insemnări la O Noapte furtunoasă, [Notes to A Stormy Night], Muzica no. 3 magazine. București: Editura Muzicală. 